\title{
Gene expression in primary cultured astrocytes affected by aluminum: alteration of chaperons involved in protein folding
}

\author{
David A. Aremu • Ojeiru F. Ezomo • \\ Shunsuke Meshitsuka
}

Received: 9 February 2010/Accepted: 31 May 2010/Published online: 22 June 2010

(c) The Japanese Society for Hygiene 2010

\begin{abstract}
Objectives Aluminum is notorious as a neurotoxic metal. The aim of our study was to determine whether endoplasmic reticulum (ER) stress is involved in aluminuminduced apoptosis in astrocytes.

Methods Mitochondrial RNA (mRNA) was analyzed by reverse transcription (RT)-PCR following pulse exposure of aluminum glycinate to primary cultured astrocytes. Tunicamycin was used as a positive control.

Results Gene expression analysis revealed that Ire $1 \beta$ was up-regulated in astrocytes exposed to aluminum while Ire $1 \alpha$ was up-regulated by tunicamycin. Exposure to aluminum glycinate, in contrast to tunicamycin, seemed to down-regulate mRNA expression of many genes, including the ER resident molecular chaperone BiP/Grp78 and $\mathrm{Ca}^{2+}$ binding chaperones (calnexin and calreticulin), as well as stanniocalcin 2 and OASIS. The down-regulation or nonactivation of the molecular chaperons, whose expressions are known to be protective by increasing protein folding, may spell doom for the adaptive response. Exposure to aluminum did not have any significant effects on the expression of $\mathrm{Bax}$ and $\mathrm{Bcl} 2$ in astrocytes.

Conclusions The results of this study demonstrate that aluminum may induce apoptosis in astrocytes via ER stress by impairing the protein-folding machinery.
\end{abstract}

D. A. Aremu · O. F. Ezomo · S. Meshitsuka $(\bowtie)$

Division of Integrative Bioscience,

Institute for Regenerative Medicine and Biofunction,

Graduate School of Medical Science, Tottori University,

Yonago, Tottori 683-8503, Japan

e-mail: mesh@med.tottori-u.ac.jp
Keywords Aluminum - Astrocyte . Unfolded protein response - ER stress . ER resident molecular chaperons

$\begin{array}{ll}\text { Abbreviations } \\ \text { ATF6 } & \text { Activating transcription factor } 6 \\ \text { Bbc3 } & \text { Bcl2 binding component } 3 \\ \text { Bcl2 } & \text { B cell lymphoma 2 } \\ \text { BiP } & \text { Immunoglobulin-binding protein } \\ \text { CHOP } & \text { C/EBP homology protein } \\ \text { GADD153 } & \text { Growth arrest and DNA damage inducible } \\ & \text { gene 153 } \\ \text { Grp78 } & \text { Glucose-regulated protein 78 } \\ \text { OASIS } & \text { Old astrocyte specifically induced substance } \\ \text { PERK } & \text { PKR-like endoplasmic reticulum kinase } \\ \text { PS2V } & \text { Aberrant splicing isoform of the presenilin-2 } \\ \text { PUMA } & \text { p53-Up-regulated modulator of apoptosis } \\ \text { RT-PCR } & \text { Reverse transcription-polymerase chain } \\ & \text { reaction } \\ \text { UPR } & \text { Unfolded protein response }\end{array}$

\section{Introduction}

The physiological roles of endoplasmic reticulum (ER) include the regulation of protein synthesis, folding and targeting, and maintenance of cellular calcium homeostasis. The ER is often perturbed when cells are deprived of essential nutrients and/or exposed to toxins or consequent upon mutations in the synthesized proteins themselves [1], resulting in the accumulation of misfolded or unfolded protein in the ER, the so-called ER stress [2]. Unfolded or misfolded proteins are harmful to cells in that cell survival itself can be threatened as a consequence [3]. In order to 
overcome ER stress, this organelle responds via activation of a specific signaling pathway generally referred to as unfolded protein response (UPR). The UPR are molecular chaperon-dependent adaptive signaling pathways that are programmed to ensure quality control within the ER by enhancing the protein folding capability and misfolded protein degradation and by limiting the load of new proteins on the ER folding apparatus. The ER relies on numerous resident chaperone proteins, a high level of calcium, and an oxidative environment to carry out these functions efficiently [4].

The aggregate effect of UPR is containment and reversal of ER stress. The UPR thereby constitutes a classic homeostatic feedback loop that adjusts the ER protein folding capacity according to need [5]. However, when misfolded proteins accumulate in excessive amounts, they may overwhelm the 'quality control' system designed to promote correct folding and eliminate faulty proteins. In the event that ER stress is not contained during a finite time window, the mammalian UPR directs the cell to an apoptotic pathway [6-10]. Apoptosis is a major form of cell death, characterized by a series of district morphological and biochemical alterations [11, 12] brought about by various physiological and pathological conditions as well as chemical agents $[11,13]$.

Aluminum is notorious as a neurotoxic chemical and has been linked to a number of neurodegenerative diseases, although such findings have been received with some controversy [14-18]. Nevertheless, several recent findings have implicated astrocytes as the principal target of the toxic action of aluminum [19-22] and that aluminum can cause astrocyte death via apoptosis [23-25]. However, these reports only showed morphological evidence of apoptosis, and the molecular mechanisms by which aluminum causes astrocyte death are yet to be unraveled. Detailed knowledge of this molecular mechanism would likely provide insight into how such cell death could be prevented. This is very important given that recent studies have demonstrated that astrocytes play active roles in neuronal regulation and modulation [26-28]. It has also been suggested that the loss of astrocyte functions may precede neurodegeneration and that aluminum could be a contributing factor [29, 30]. For example, astrocytes have been shown to undergo an active process of apoptosis in Alzheimer's disease (AD) [31] and that this process may precede the death of neurons [32]. Moreover, chronic exposure to aluminum has been reported to accelerate the production of the aberrant splicing isoform of presenilin-2 (PS2V), a diagnostic feature of sporadic AD [33]. PS2V protein has also been found to affect the UPR and cause an increase in the production of both amyloid beta $(\mathrm{A} \beta)-40$ and $\mathrm{A} \beta-42$ [34]. Furthermore, mutations in the presenilin gene have been reported to cause the inhibition of the ER stress transducers Ire 1, activating transcription factor (ATF)6, and PKR-like endoplasmic reticulum kinase (PERK), resulting in the decreased expression of ER chaperons [35].

The aim of the study reported here was to determine how aluminum exposure affects the expression of a number of important ER stress-related genes, given the likely link between aluminum and ER stress and the observed apoptosis in astrocytes reported in earlier studies [23, 25, 30]. The B cell lymphoma $2(\mathrm{Bcl} 2)$ family of proteins was also studied to clarify the contributions of ER and mitochondria in the pathways involved in aluminum-induced apoptosis in cultured astrocytes.

\section{Materials and methods}

\section{Primary culture}

Primary cultures of cortical astrocytes were prepared from 5- to 7-day-old mice as previously described [24]. Briefly, the cells were grown in D-MEM/F12 or D-MEM during the experimental period (cat. no. 11330 or 11885; GIBCO BRL, Life Technologies, Grand Island, NY) containing $10 \%$ fetal bovine serum (GIBCO BRL) and $0.05 \mathrm{mg} / \mathrm{ml}$ gentamicin (Sigma, St. Louis, MO), incubated at $37^{\circ} \mathrm{C}$ in humidified atmosphere of $5 \% \mathrm{CO}_{2}$, and used for experiments at near confluence after second passages by trypsinization. In all experiments, the cells were stressed with $0.1 \mathrm{mM}$ aluminum glycinate (Tokyo Kasei Kogyo, Japan) for $48 \mathrm{~h}$ or with a 6 - to 12 -h pulse exposure followed by continued culture in normal medium for about 7 days. In some experiments, concentrations lower or higher than $0.1 \mathrm{mM}$ were employed to assess concentration-dependent effects. Previous morphological studies on apoptosis did not find any adverse effects on cell viability/proliferation among cells exposed to test compounds at concentrations similar to those employed in our study [24].

\section{Western blot analysis}

Cells were lysed on ice for 10 min with lysis buffer containing $10 \mathrm{mM}$ HEPES-KOH (pH 7.8), $10 \mathrm{mM} \mathrm{KCl,} 1 \mathrm{mM}$ EDTA (pH 8.0), 0.05\% NP-40, 1 mM DTT plus protease inhibitor cocktail (Roche, Mannheim, Germany) followed by brief homogenization with sonication. Aliquots of cell lysates $(20 \mu \mathrm{g} / \mathrm{ml})$ were resolved by sodium dodecyl sulfate-polyacrylamide gel electrophoresis on $10-12 \%$ polyacrylamide gels and transferred onto a $0.2-\mu \mathrm{m}$ Immun-blot PVDF membrane for protein blotting (Bio-Rad, Hercules, CA). The membranes were incubated overnight in 5 or $10 \%(\mathrm{w} / \mathrm{v})$ skim milk in $0.1 \%$ TBS-T, then stained with the respective monoclonal primary antibodies followed by horseradish peroxidase-conjugated second antibody. The 
Table 1 Primers of target genes

See text and abbreviation list for the full names of the target genes

\begin{tabular}{lllc}
\hline Target gene & Forward primer & Reverse primer & $\begin{array}{l}\text { Product } \\
\text { size }(\mathrm{bp})\end{array}$ \\
\hline Ire1 $\alpha$ & CCCAAATGTGATCCGCTACT & TTGAGAGAATGCAGGTGTGC & 183 \\
Ire1 $\beta$ & ACTGTGGATCCAGGAAGTGG & TGGCTGTGTCTTGGTAGCTG & 193 \\
ATF6 $\alpha$ & GGCCAGACTGTTTTGCTCTC & CCCATACTTCTGGTGGCACT & 215 \\
ATF6 $\beta$ & GGGTCCATCCCCTGATAGTT & CACCTTGGATGAGGACCACT & 185 \\
PERK/Eif2ak3 & CGGATTCATTGAAAGCACCT & ACGCGATGGGAGTACAAAAC & 194 \\
Bbc3/PUMA & GCCCAGCAGCACTTAGAGTC & TGTCGATGCTGCTCTTCTTG & 191 \\
Bip/Grp78 & TGGAGTTCCCCAGATTGAAG & GCGCTCTTTGAGCTTTTTGT & 199 \\
CHOP/GADD153 & CCTAGCTTGGCTGACAGAGG & CTGCTCCTTCTCCTTCATGC & 196 \\
Stanniocalcin 2 & TCCAGCAATTAGGGAAATGG & CCCAGCTCTGTTCACACTGA & 230 \\
Calnexin & GGCTAGACGACGAACCTGAG & AGGCTTCCATTTGCCCTTAT & 188 \\
Calreticulin & AGGCTCCTTGGAGGATGATT & TCCCACTCTCCATCCATCTC & 207 \\
OASIS & ACCTGGACCACTTTGTGGAG & TGGTGTCCTCCATCTTGACA & 210 \\
\hline
\end{tabular}

luminescence reaction was elicited using an ECL kit (Amersham, Piscataway, NJ) and the protein bands were visualized using a computer-aided FUJIFILM Luminescent Image Analyzer (LAS-1000plus; Fuji Photo Film, Tokyo). The same membrane was stripped for all subsequent analyses. The antibodies used were: mouse monoclonal anti-B cell lymphoma (Bcl-2; C-2), anti-Bcl-2-associated X (Bax; B-9) (Santa Cruz Biotechnology, Santa Cruz, CA), and anti- $\alpha$-tubulin (Ab-1) (Oncogene, San Diego, CA).

Reverse transcription-PCR analysis

Validation of the effect of aluminum on the expression of selected genes was performed by reverse transcription (RT)-PCR analysis (BioRad) using apoptosis PCR bax/bcl2 multiplex primer sets (APO-PCR; Sigma-Aldrich, Saint Louis, MO). Unique oligonucleotide primer pairs of genes that have been implicated in ER stress-induced apoptosis were designed (Table 1) using PRIMER3 software (http:// www.genome.wi.mit.edu/cgi-bin/primer3_www.cgi) [36]. Total RNA was purified from aluminum-treated and untreated control cells using the Mini RNeasy kit (QIAGEN, Valencia, CA). The ER stress inducer tunicamycin, a protein $N$-glycosylation inhibitor, was employed as a positive control. The purified RNA was subjected to RT-PCR in a two-step protocol using M-MLV reverse transcriptase (Invitrogen, Grand Island, NY) and Taq polymerase (Applied Biosystems, Foster City, CA). The number of cycles and annealing temperature was according to the manufacturer's protocol for APO-PCR. The bands in the photographs were quantified by Image $\mathrm{J} 1.43 \mathrm{u}$ software. The animal experiments were approved by the committee on animal research of Tottori University, and the investigation conforms to the guiding principles for the care and use of laboratory animals in toxicology.

\section{Results}

The anti-apoptotic $\mathrm{Bcl} 2$ and pro-apoptotic Bax are wellstudied members of the $\mathrm{Bcl} 2$ family of proteins that respectively inhibit or enhance cytochrome $c$ release under mitochondria-controlled apoptosis. Hence, the expressions of these two proteins were studied by Western blotting analysis following exposure of primary cultured astrocytes to aluminum as described in the Materials and methods. Aluminum glycinate did not affect the expression of these two proteins under different exposure regimens and various doses, including pulse exposure followed by continued culture in normal medium for 7 days (Fig. 1a). Tunicamycin was employed as the positive control in subsequent experiments. Total RNA was extracted from the cells, and the mRNAs of the $\mathrm{Bcl} 2$ and Bax genes were observed using RT-PCR. Exposure to either tunicamycin or aluminum glycinate did not evoke any observable change in the expression of these genes (Fig. 1b). Cells exposed to tuinicamycin, however, did show an up-regulation of the expression of the pro-apoptotic gene, $\mathrm{Bcl} 2$ binding component 3/p53-up-regulated modulator of apoptosis (Bbc3/ PUMA), another member of the Bcl-2 family [37], while aluminum had no apparent effect effect on its expression under different exposure regimens (Fig. 2).

Ire $1 \alpha$ is the most studied of the two isoforms of the Ire 1 gene; consequently, we first analyzed primary cultured astrocytes exposed to aluminum glycinate or tunicamycin for 6,12 , or $24 \mathrm{~h}$ for changes in the expression of the Ire 1 gene (Fig. 3a). The results showed that aluminum seemed to have only a minor effect on the expression of Ire $1 \alpha$, similar to that seen in the control experiment, and that this effect was time dependent. In contrast, tunicamycin up-regulated the expression of Ire $1 \alpha$ relative to the control at the 12 - and $24-\mathrm{h}$ timepoints (Fig. 3b). We then investigated Ire1 $\beta$ gene 


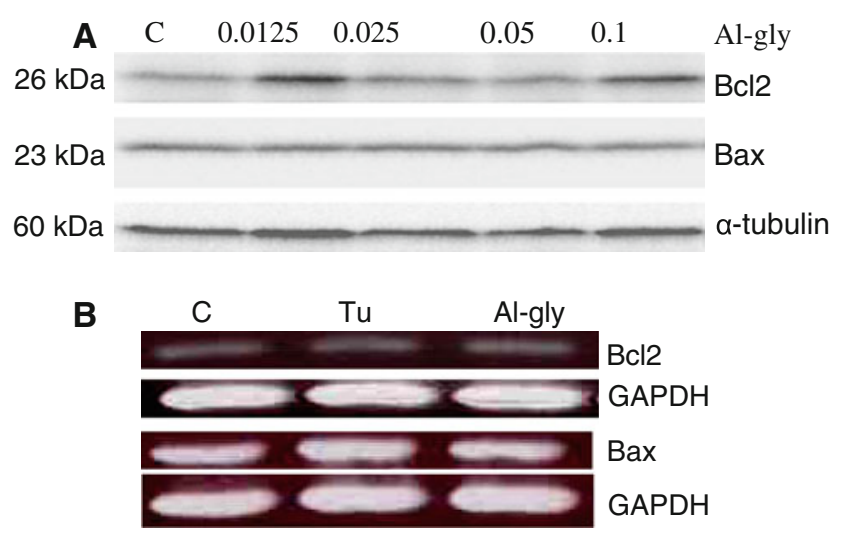

Fig. 1 The expression of the B cell lymphoma 2 ( $B c l 2)$ family of proteins in primary cultured astrocytes in the presence of aluminum. a Western blot analysis of Bcl-2-associated X (Bax) and Bcl2 protein expression in primary astrocytes cultured in the absence ( $C$ control) or presence of graded doses of aluminum glycinate (Al-gly; 0.0125$0.1 \mathrm{mM}$ ) for $24 \mathrm{~h}$. The membrane was stained with $\mathrm{Bcl} 2$ monoclonal primary antibodies followed by horseradish peroxidase-conjugated second antibody. The same membrane was subsequently stripped for Bax and $\alpha$-tubulin analyses. The results are representative of about six blots obtained from three different exposure regimens. b Bcl2 and Bax mRNA expressions in primary astrocytes cultured for $24 \mathrm{~h}$ in the absence $(C$ control) or presence of tunicamycin $(T u, 5 \mu \mathrm{g} / \mathrm{ml})$ and Algly $(0.1 \mathrm{mM})$. Total RNA was analyzed by reverse transcription (RT)-PCR for the expression of Bcl2 and Bax. Glyceraldehyde 3phosphate dehydrogenase $(G A P D H)$ was analyzed as internal standard. The results are representative of three independent analyses from two replicate cultures

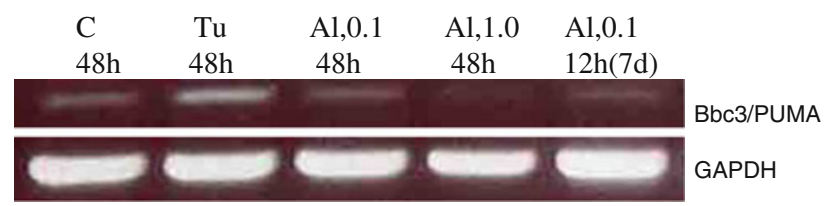

Fig. 2 Semiquantitative RT-PCR analysis of the expression of Bcl2 binding component 3/p53-up-regulated modulator of apoptosis (Bbc3/ $P U M A)$ in the presence of aluminum. Total RNA was analyzed by RT-PCR for the mRNA expressions of Bbc3/PUMA in primary cultured astrocytes. Cells were treated with $\mathrm{Tu}(5 \mu \mathrm{g} / \mathrm{ml})$ for $48 \mathrm{~h}$ or Al-gly $(\mathrm{Al} ; 0.1$ or $1.0 \mathrm{mM})$ for 48 or for $12 \mathrm{~h}$ followed by a 7-day culture in normal medium. GAPDH mRNA was analyzed as the internal control. The results are representative of three independent analyses from two replicate cultures

expression using both Ire $1 \beta$ and Ire $1 \alpha$ primers. The cells were exposed to aluminum or tunicamycin for $48 \mathrm{~h}$ or aluminum for $12 \mathrm{~h}$ followed by culture in normal medium for 7 days. Under this exposure regimen, in contrast to Ire $1 \alpha$, the expression of Ire $1 \beta$ was not detectable in either the control or tunicamycin-treated cells, and only aluminum glycinate upregulated Ire $1 \beta$ in cells that had been exposed to pulses of aluminum followed by culture in normal medium for 7 days (Fig. 4a, b). The up-regulation of Ire $1 \alpha$ by tunicamycin was more than twice that observed in the control cultures at the 48-h timepoint (Fig. 4b) and was similar to that observed 12
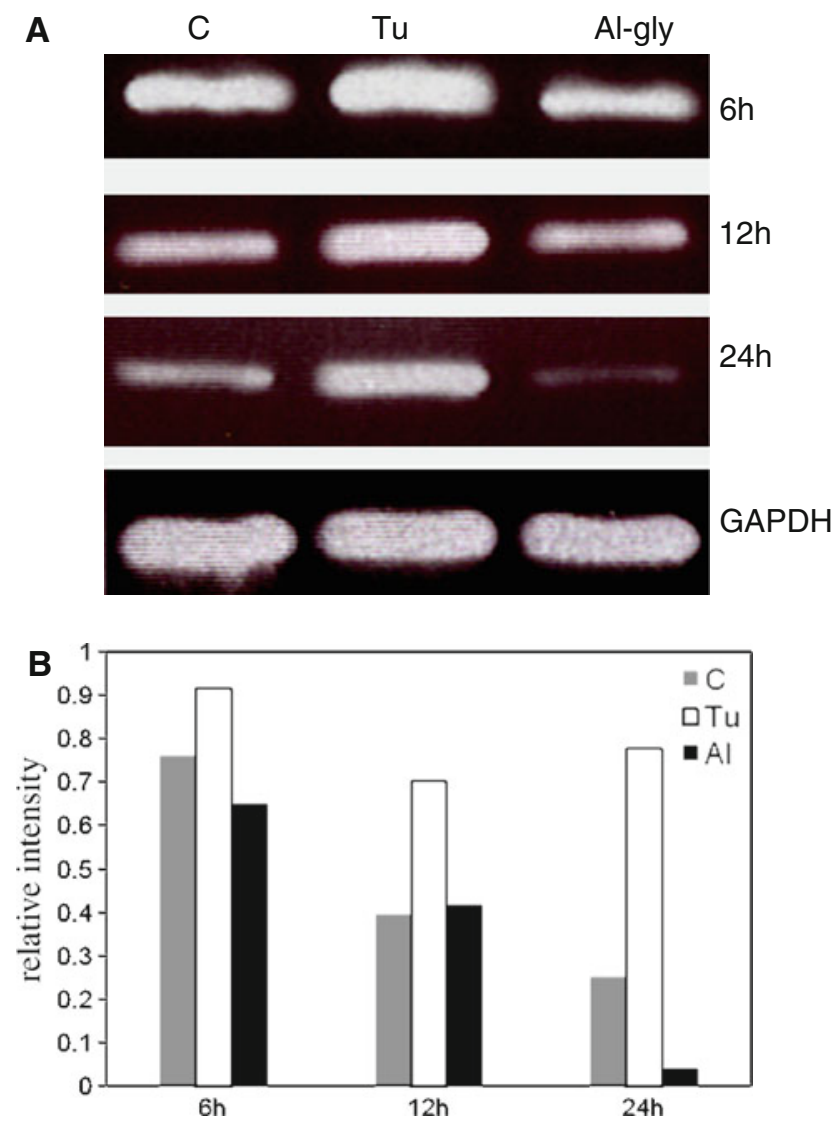

Fig. 3 a Semiquantitative RT-PCR analysis of Ire $1 \alpha$ genes in primary cultured astrocytes following time-course exposure to aluminum. Total RNA was analyzed by RT-PCR for the kinetics of Ire $1 \alpha$ mRNA expression in primary cultured astrocytes for the indicated times in the absence ( $C$ control) or presence of Tu $(5 \mu \mathrm{g} / \mathrm{ml})$ or Al-gly $(0.1 \mathrm{mM})$. GAPDH mRNA was also analyzed as an internal standard. The results are representative of three independent analyses from two replicate cultures. b Relative intensities of the bands

and $24 \mathrm{~h}$ of exposure (Fig. 3b). Other principal components of the UPR pathway, including PERK, ATF6 $\alpha$ and ATF6 $\beta$, were were studied (Fig. 5). PERK was not detectable in either the control or tunicamycin- and aluminum-treated cells. ATF6 $\alpha$ was up-regulated in tunicamycin-treated cells only, while neither ATF6 $\alpha$ nor ATF6 $\beta$ was up-regulated in aluminum-treated cells.

Expression of the $\mathrm{Ca}^{2+}$ homeostasis related genes, including stanniocalcin 2 (STC2), calreticulin, and calnexin, were examined in cells exposed to aluminum or tunicamycin for $24 \mathrm{~h}$. STC2 was not detectable in the control cells and aluminum-treated cells, but this gene was up-regulated in tunicamycin-treated cells. Tunicamycin also slightly up-regulated calreticulin and calnexin, while aluminum appeared to to have no effect on the expression of these genes (Fig. 6).

Primary cultured astrocytes were exposed to aluminum glycinate for various lengths of time, and tunicamycin was employed as the positive control. While tunicamycin 
A
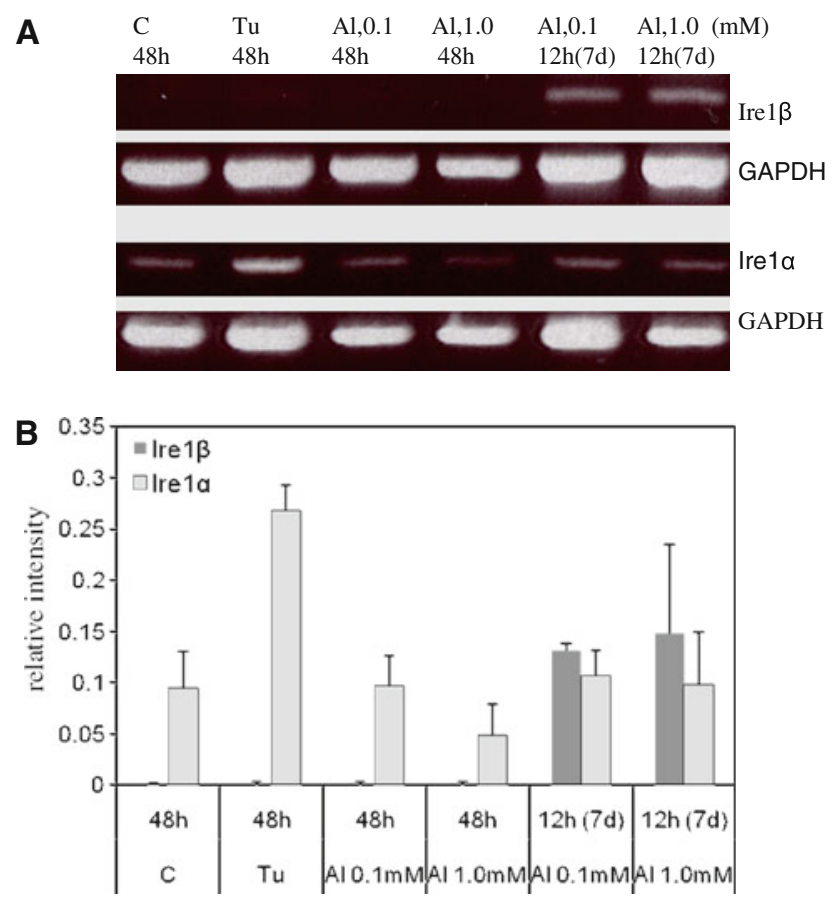

Fig. 4 a Semiquantitative RT-PCR analysis of Ire $1 \beta$ And Ire $1 \alpha$ genes in primary cultured astrocytes following exposure to aluminum and $\mathrm{Tu}$ for the indicated time. Pulse exposure to aluminum followed by continued culture for 7 days in normal medium resulted in up-regulation of the expression of $\operatorname{Ire} 1 \beta$ in primary cultured astrocytes. Total RNA was analyzed by RT-PCR for Ire $1 \alpha$ and $\operatorname{Ire} 1 \beta$ mRNA expression in primary cultured astrocytes. Cells were treated with $\mathrm{Tu}(5 \mu \mathrm{g} / \mathrm{ml})$ for $48 \mathrm{~h}$ or Al-gly $(A l ; 0.1$ or $1.0 \mathrm{mM})$ for 48 or for $12 \mathrm{~h}$ followed by 7 days of culture in normal medium. GAPDH mRNA was also analyzed as the internal standard. The results are representative of three independent analyses from two replicate cultures. b Relative intensities of the bands (mean \pm standard deviation, $n=3$ )

up-regulated the expression of immunoglobulin-binding protein/glucose-regulated protein $78(\mathrm{BiP} / \mathrm{Grp} 78)$ gene, aluminum modestly down-regulated the expression of this gene (Fig. 7). The expressions of transcription factors, CEBP homologous protein (CHOP/GADD153)-coding gene and old astrocyte specifically induced substance (OASIS), an ER stress transducer in astrocytes, were also examined following exposure to aluminum or tunicamycin. Tunicamycin up-regulated the expression of these genes but aluminum did not affect their expression after $24 \mathrm{~h}$ exposure (Fig. 8).

\section{Discussion}

Executioners of apoptosis are known to function in different cellular compartments and act on distinct substrates, but there is only a limited body of knowledge on the contribution of organelles, such as the ER, to the apoptotic process [38]. There is, however, increasing evidence that the ER can play pivotal roles in regulating cell survival and

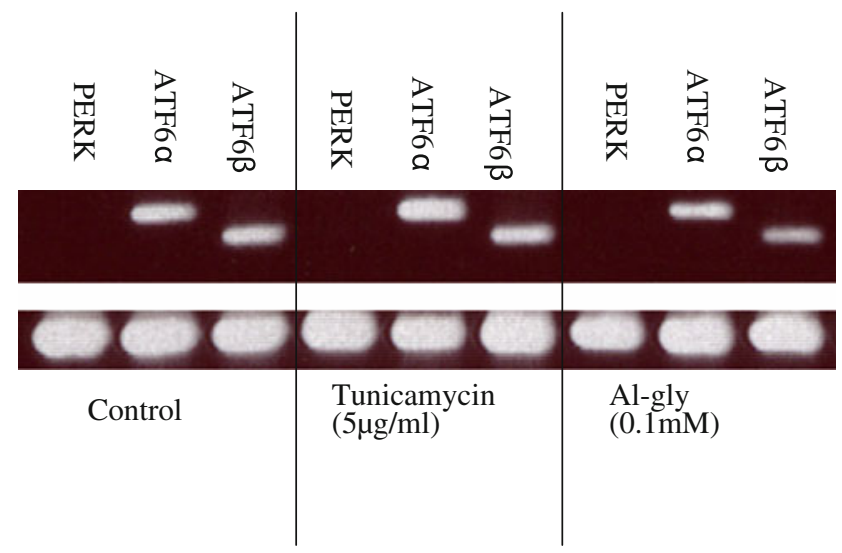

Fig. 5 Semiquantitative RT-PCR analysis of selected genes in primary cultured astrocyte following $12 \mathrm{~h}$ of exposure to aluminum and some known apoptotic agents. Aluminum did not affect the expression of activating transcription factors $(A T F) 6 \alpha$ and $\beta$. Total RNA was analyzed by RT-PCR for the mRNA expressions of PKRlike endoplasmic reticulum kinase (PERK), ATF6 $\alpha$ and $\beta$ and GAPDH in primary cultured astrocytes. Cells were treated with tunicamycin $(5 \mu \mathrm{g} / \mathrm{ml})$ or Al-gly $(0.1 \mathrm{mM})$ for $12 \mathrm{~h}$. The results are representative of three independent analyses from two replicate cultures

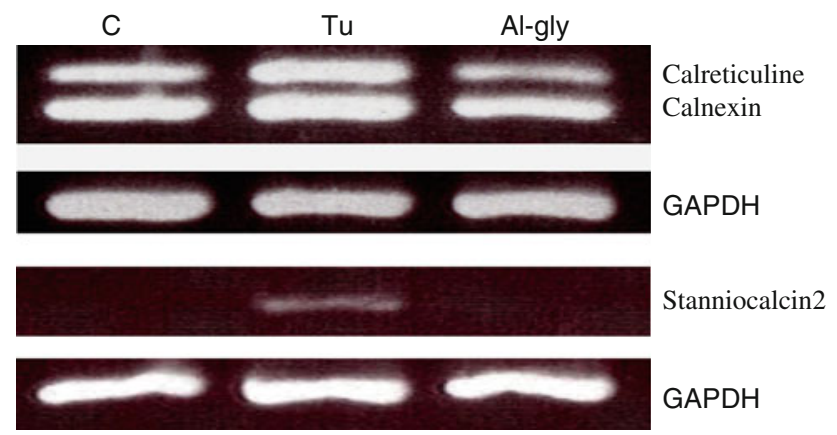

Fig. 6 Semiquantitative RT-PCR analysis of selected genes in primary cultured astrocytes following $24 \mathrm{~h}$ of exposure to aluminum (Al-gly; $0.1 \mathrm{mM})$ and $\mathrm{Tu}(5 \mu \mathrm{g} / \mathrm{ml})$. Tu, but not Al-gly, up-regulated the expression of calreticuline, calnexin, and stanniocalcin 2. Total RNA was analyzed by multiplex RT-PCR for the mRNA expressions of calreticuline, calnexin, stanniocalcin 2, and GAPDH. The results are representative of three independent analyses from two replicate cultures

apoptosis in a variety of cell types, including neurons and astrocytes. The results of our study demonstrate that ER stress may be involved in aluminum-induced apoptosis in astrocytes, although we found no evidence of the participation of the mitochondrial-associated pathway in this process. There was no up-regulation of either the protein or mRNA expression of the anti-apoptotic $\mathrm{Bcl} 2$ and proapoptotic Bax. Bcl2 and Bax are known to inhibit and enhance, respectively, cytochrome $c$ release in the mitochondria apoptotic pathway $[39,40]$. The release of cytochrome $c$ from the intermembrane space into the cytoplasm usually results in the activation of caspase 3 , which in turn 
A $\quad \mathrm{C} \quad \mathrm{Tu} \quad \mathrm{Al}, 0.1 \quad \mathrm{Al}, 1.0 \quad \mathrm{Al}, 0.1 \quad \mathrm{Al}, 1.0(\mathrm{mM})$

\begin{tabular}{|c|c|c|c|c|c|c|}
\hline $48 \mathrm{~h}$ & $48 \mathrm{~h}$ & $48 \mathrm{~h}$ & $48 \mathrm{~h}$ & $12 \mathrm{~h}(7 \mathrm{~d})$ & $12 \mathrm{~h}(7 \mathrm{~d})$ & \\
\hline & & $=$ & $=$ & $=$ & $=$ & BiP/Grp78 \\
\hline
\end{tabular}

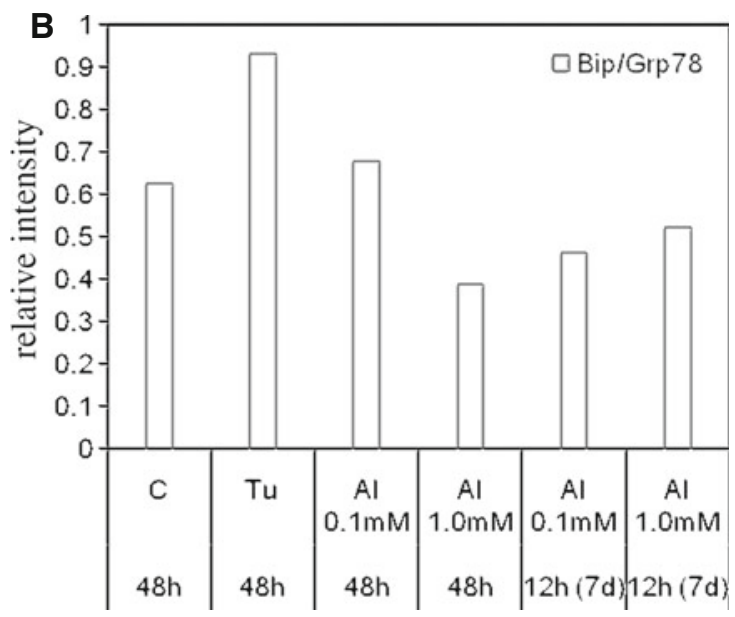

Fig. 7 a Semiquantitative RT-PCR analysis of the immunoglobulinbinding protein/glucose-regulated protein 78 (BiP/Grp78) gene in primary cultured astrocytes following exposure to aluminum (Al-gly; $A l)$ and $\mathrm{Tu}$ for the indicated time periods. Total RNA was analyzed by RT-PCR for the mRNA expression of Bip/Grp78. Al-gly did not upregulate the expression of Bip/Grp78. Cells were treated with $\mathrm{Tu}$ $(5 \mu \mathrm{g} / \mathrm{ml})$ for $48 \mathrm{~h}$ or with Al-gly for 48 or for $12 \mathrm{~h}$ followed by 7 days of culture in normal medium. The results are representative of three independent analyses from two replicate cultures. b Relative intensities of the bands

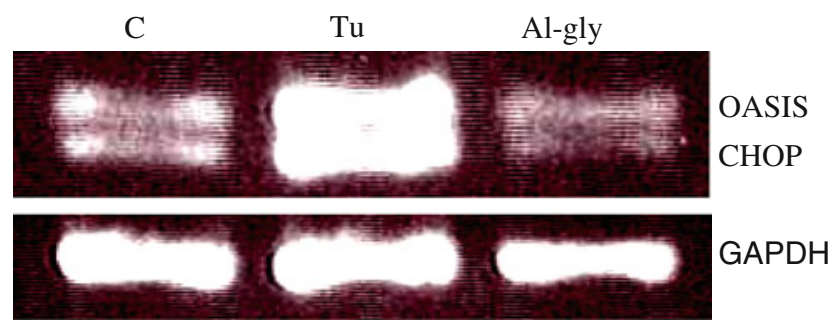

Fig. 8 Semiquantitative RT-PCR analysis of selected genes from primary cultured astrocyte following $24 \mathrm{~h}$ of exposure to aluminum and Tu. The expressions of C/EBP homology protein $(\mathrm{CHOP})$ and old astrocyte specifically induced substance $(O A S I S)$ was not stimulated by exposure to Al-gly. Total RNA was analyzed by multiplex RTPCR for the mRNA expressions of CHOP, OASIS, and GAPDH in primary cultured astrocytes. Cells were treated with $\mathrm{Tu}(5 \mu \mathrm{g} / \mathrm{ml})$ or Al-gly $(0.1 \mathrm{mM})$ for $24 \mathrm{~h}$. The results are representative of three independent analyses from two replicate cultures

activates the downstream execution phase of apoptosis. Interestingly, tunicamycin, but not aluminum, up-regulated mRNA of Bbc3/PUMA, a pro-apoptotic member of the Bcl-2 family that mediates p53-dependent and -independent apoptosis [41].

Experiments with yeast have revealed that Ire1 is the most proximal component of the UPR pathway [42]. The two isoforms identified in the mammalian genome are
Ire $1 \alpha$ and Ire $1 \beta[43,44]$. Other known proximal sensors of the UPR in metazoan species are PERK and ATF6 [45]. Together with Ire1, PERK and ATF6 regulate components that act to suppress the initiation of protein synthesis, upregulate the capacity of the ER to fold newly synthesized proteins, and degrade misfolded/unfolded protein [4]. Under non-stressed conditions, Bip (Grp78), an ATPdependent ER chaperone, binds to the three ER resident transmembrane proteins (i.e., Ire1, PERK, and ATF6) which negatively regulate the UPR by keeping these proteins in an inactivated state [46]. When misfolded proteins accumulate in the ER, BiP/GRP78 binds instead to misfolded proteins [47-49] and allows activation of these UPR sensors, leading to decreased protein synthesis and the increased production of ER chaperones [46, 50]. Our results show that of these three proximal sensors, aluminum exposure only up-regulated Ire1 $\beta$, while BiP/GRP78 (an ER resident chaperone) was down-regulated. Tunicamycin, on the other hand, up-regulated both Ire $1 \alpha$ and $\mathrm{BiP} /$ GRP78 under similar conditions. The differential effects of tunicamycin and aluminum on $\operatorname{Ire} 1 \alpha$ and $\operatorname{Ire} 1 \beta$ may indicate differences in their UPR mechanism.

Both Ire $1 \alpha$ and $\operatorname{Ire} 1 \beta$ possess kinase activity that is required for activating downstream signaling [43], but it is not yet understood how aluminum and tunicamycin differentially regulate their expression in astrocytes. Ire $1 \alpha$ is known to be constitutively expressed in all cells and tissues, whereas Ire $1 \beta$ expression is known to be restricted to gut epithelial cells [45]. Although Ire1 $\beta$ was not detectable in unstressed primary astrocytes, aluminum-stressed astrocytes were able to up-regulate this factor to the level approximating that of Ire $1 \alpha$ (Fig. 4b). To the best of our knowledge, this is the first report to show the significant expression of Ire $1 \beta$ in the nervous tissue, but the significance of this finding remains to be elucidated. Nevertheless, over-expression of $\operatorname{Ire} 1 \alpha$ and $\operatorname{Ire} 1 \beta$ can activate a reporter gene that harbors an ER stress-response element (ERSE) in a manner that requires the endoribonuclease activity of Ire1 [43]. Thus, the up-regulation of $\operatorname{Ire} 1 \beta$ by aluminum glycinate in our study under an exposure regimen similar to that previously reported in a study reporting morphological evidence of apoptosis [24] demonstrates the involvement of ER stress. Therefore, Ire $1 \alpha$ may not be essential for the transcriptional induction of several wellcharacterized UPR target genes [45], and Ire $1 \alpha$ and Ire $1 \beta$ may be differentially induced, depending on the stimulus and/or tissue. Further studies may clarify this hypothesis.

Aluminum glycinate, in contrast to tunicamycin, seemed to down-regulate - or have no effect at all-the expression of many genes, including the ER resident molecular chaperon $\mathrm{BiP} / \mathrm{GRP} 78$ and $\mathrm{Ca}^{2+}$ binding chaperones (calnexin and calreticulin) as well as STC2, and transcription factors, such as the CEBP homologous protein 
(CHOP/GADD153)-coding gene and OASIS. Calnexin, a type I integral membrane protein of the ER, exhibits a high degree of amino acid sequence and structural similarity (identity) to its soluble homolog, calreticulin [51], and appears to perform similar functions. Both proteins are chaperones whose functions include $\mathrm{Ca}^{2+}$ binding, lectinlike activity, and the recognition of misfolded proteins [52]. Both proteins are important for $\mathrm{Ca}^{2+}$ homeostasis and directly affect the folding and post-translational modification of virtually all glycosylated, secreted, or integral membrane proteins that pass through the ER [53-55]. The majority of cell-surface receptors, channels, and transporters as well as proteins that reside in intracellular organelles, including the ER, are glycosylated. BiP/GRP78, another ER resident chaperone, appears to play an important role in the folding and post-translational modification of non-glycosylated proteins $[52,56]$. Thus, non-induction or down-regulation of these chaperones may affect diverse of cellular functions in addition to protein folding [57].

STC2 is a novel target of the mammalian UPR that shares limited sequence similarity with an anti-hypercalcemic hormone first discovered in fish [58]. Two widely expressed STC-related proteins, STC1 and STC2, have been identified in mammals where they have been implicated in mineral metabolism [59, 60]. STC2 expression has been shown recently to be induced in cultured cells by ER stress agents, and attenuation of its expression during the UPR renders mouse N2a neuroblastoma cells and HeLa cells vulnerable to cell death elicited by thapsigargin, whereas over-expression of STC2 protects cells against thapsigargin-induced apoptotic cell death [61]. In our study, only tunicamycin up-regulated STC2, while its expression was not detectable in both control and aluminum-stressed astrocytes. Another significant protein studied is OASIS, an ER stress transducer specific to astrocytes. OASIS is a membrane-bound transcription factor that activates genes in the ER stress response [62]. Overexpression of OASIS has been reported to result in the induction of BiP/GRP78 and suppression of ER-stressinduced cell death, whereas its knockdown partially reduced BiP/GRP78 levels and led to ER stress in susceptible astrocytes [63]. Our results show that OASIS, which provides astrocytes with resistance to ER stress, was not activated in the presence of aluminum when compared to tunicamycin and that this may render astrocytes susceptible to death. Thus, the down-regulation or non-activation of the molecular chaperones and transcription factors whose expressions are known to be protective by increasing protein folding and limiting further accumulation of misfolded proteins may spell doom for the adaptive response that promotes cell survival.

Conditions that impair protein folding in the ER and thus promote the accumulation of mutant proteins have a significant adverse effect on cellular survival. A number of diseases have been linked to the toxic effects of mutant proteins that accumulate in the ER [64]. For example, the misfolding of secreted $\mathrm{A} \beta$ 39-43 residues in terms of length is linked by a plethora of evidence to the pathology of AD [65-67]. Moreover, mutations in the presenilin gene have been reported to cause the inhibition of ER stress transducers, Ire1, ATF6, and PERK, resulting in the decreased expression of ER chaperons [35]. The aberrant splicing isoform (PS2V) generated by skipping exon5 of the presenilin-2 (PS2) gene is a diagnostic feature of sporadic $\mathrm{AD}(\mathrm{SAD})$. It has been demonstrated that chronic exposure to aluminum accelerates PS2V production induced by hypoxia in human neuroblastoma cells [33]. PS2V has also been reported to cause significant increases in the production of both $\mathrm{A} \beta 40$ and $\mathrm{A} \beta 42$ [34]. The inhibition of ER chaperones, such as BiP/GRP78 and calnexin, has also been linked to the increased production of the level of $\mathrm{A} \beta 40$ and $\mathrm{A} \beta 42$ in conditioned medium of cells that produce mutant types of APP [68]. Thus, further studies are needed to clarify the links between aluminum, PS2V, ER chaperones, and the accumulation of unfolded proteins and neurodegenerative disorders. In fact, neurodegenerative disorders such as AD, Parkinson disease (PD), Huntingtons disease, amyotrophic lateral sclerosis or Lou Gehrig's disease, and prion protein diseases as well as their transgenic animal models all feature misfolded proteins and the aggregation of misfolded proteins [21, 69-72]. Although the specific role played by misfolded proteins in disease pathogenesis remains elusive [46], several authors have reported that neuronal death occurring in $\mathrm{AD}, \mathrm{PD}$, and cerebral ischemia has its origin in the ER [35]. ER stress pathways and the subsequent cellular responses may provide a mechanistic connection between misfolded proteins and disease [48].

Acknowledgments This work was supported in part by the subsidy from the Ministry of Health, Labor, and Welfare of Japan, and by the Ichiro Kanehara Foundation.

\section{References}

1. Lee AS. Mammalian stress response: induction of the glucoseregulated protein family. Curr Opin Cell Biol. 1992;4:267-73.

2. Kaufman RJ. Stress signaling from the lumen of the endoplasmic reticulum: coordination of gene transcriptional and translational controls. Genes Dev. 1999;13:1211-33.

3. Kopito RR. Aggresomes, inclusion bodies and protein aggregation. Trends Cell Biol. 2000;10:524-30.

4. Rao RV, Ellerby HM, Bredesen DE. Coupling endoplasmic reticulum stress to the cell death program. Cell Death Differ. 2004; 11:372-80.

5. Credle JJ, Finer-Moore JS, Papa FR, Stroud RM, Walter P. On the mechanism of sensing unfolded protein in the endoplasmic reticulum. Proc Natl Acad Sci USA. 2005;102:18773-84. 
6. Chandler JM, Cohen GM, MacFarlane M. Different subcellular distribution of caspase-3 and caspase-7 following Fas-induced apoptosis in mouse liver. J Biol Chem. 1998;273:10815-8.

7. Nakagawa T, Zhu H, Morishima N, Li E, Xu J, Yankner BA, et al. Caspase-12 mediates endoplasmic-reticulum-specific apoptosis and cytotoxicity by amyloid-beta. Nature. 2000;403: 98-103.

8. Taylor MH, Buckwalter MR, Stephenson AC, Hart JL, Taylor BJ, O'Neill KL. Radiation-induced apoptosis in MOLT-4 cells requires de novo protein synthesis independent of de novo RNA synthesis. FEBS Lett. 2002;514:199-203.

9. Urano F, Bertolotti A, Ron D. IRE1 and efferent signaling from the endoplasmic reticulum. J Cell Sci. 2000;113:3697-702.

10. Zinszner H, Kuroda M, Wang X, Batchvarova N, Lightfoot RT, Remotti $\mathrm{H}$, et al. CHOP is implicated in programmed cell death in response to impaired function of the endoplasmic reticulum. Genes Dev. 1998;12:982-95.

11. Arends MJ, Wyllie AH. Apoptosis: mechanisms and roles in pathology. Int Rev Exp Pathol. 1991;32:223-54.

12. Kerr JB, Knell CM, Abbott M, Donachie K. Ultrastructural analysis of the effect of ethane dimethanesulphonate on the testis of the rat, guinea pig, hamster and mouse. Cell Tissue Res. 1987;249:451-7.

13. Cohen GM, Sun XM, Snowden RT, Dinsdale D, Skilleter DN. Key morphological features of apoptosis may occur in the absence of internucleosomal DNA fragmentation. Biochem J. 1992;286:331-4.

14. Mizoroki T, Meshitsuka S, Maeda S, Murayama M, Sahara N, Takashima A. Aluminum induces tau aggregation in vitro but not in vivo. J Alzheimers Dis. 2007;11:419-27.

15. Meshitsuka S, Aremu DA, Nose T. A risk of Alzheimer's disease and aluminum in drinking water. Psychogeriatrics. 2002;2:263-8.

16. Rondeau V, Jacqmin-Gadda H, Commenges D, Helmer C, Dartigues JF. Aluminum and silica in drinking water and the risk of Alzheimer's disease or cognitive decline: findings from 15-year follow-up of the PAQUID cohort. Am J Epidemiol. 2009; 169:489-96.

17. Yasui M, Yase Y, Ota K, Mukoyama M, Adachi K. High aluminum deposition in the central nervous system of patients with amyotrophic lateral sclerosis from the Kii Peninsula, Japan: two case reports. Neurotoxicology. 1991;12:277-83.

18. Forster DP, Newens AJ, Kay DW, Edwardson JA. Risk factors in clinically diagnosed presenile dementia of the Alzheimer type: a case-control study in northern England. J Epidemiol Community Health. 1995;49:253-8.

19. Campbell A, Hamai D, Bondy SC. Differential toxicity of aluminum salts in human cell lines of neural origin: implications for neurodegeneration. Neurotoxicology. 2001;22:63-71.

20. Guo-Ross SX, Yang EY, Walsh TJ, Bondy SC. Decrease of glial fibrillary acidic protein in rat frontal cortex following aluminum treatment. J Neurochem. 1997;73:1609-14.

21. Rao KS. Effect of aluminium (Al) on the brain cells of the rat. Biochem Int. 1992;28:51-6.

22. Struys-Ponsar C, Guillard O, van den Bosch de Aguilar P. Effects of aluminum exposure on glutamate metabolism: a possible explanation for its toxicity. Exp Neurol. 2000;163:157-64.

23. Guo GW, Liang YX. Aluminum-induced apoptosis in cultured astrocytes and its effect on calcium homeostasis. Brain Res. 2001;888:221-6.

24. Aremu DA, Meshitsuka S. Accumulation of aluminum by primary cultured astrocytes from aluminum amino acid complex and its apoptotic effect. Brain Res. 2005;1031:284-96.

25. Suarez-Fernandez MB, Soldado AB, Sanz-Medel A, Vega JA, Novelli A, Fernandez-Sanchez MT. Aluminum-induced degeneration of astrocytes occurs via apoptosis and results in neuronal death. Brain Res. 1999;835:125-36.
26. Oliet SH, Piet R, Poulain DA. Control of glutamate clearance and synaptic efficacy by glial coverage of neurons. Science. 2001;292:923-6.

27. Piet R, Poulain DA, Oliet SH. Contribution of astrocytes to synaptic transmission in the rat supraoptic nucleus. Neurochem Int. 2004;45:251-7.

28. Simard M, Nedergaard M. The neurobiology of glia in the context of water and ion homeostasis. Neuroscience. 2004;129:87796.

29. Rothstein JD, Dykes-Hoberg M, Pardo CA, Bristol LA, Jin L, Kuncl RW, et al. Knockout of glutamate transporters reveals a major role for astroglial transport in excitotoxicity and clearance of glutamate. Neuron. 1996;16:675-86.

30. Aremu DA, Meshitsuka S. Some aspects of astroglial functions and aluminum implications for neurodegeneration. Brain Res Rev. 2006;52:193-200.

31. Smale G, Nichols NR, Brady DR, Finch CE, Horton WE. Evidence for apoptotic cell death in Alzheimer's disease. Exp Neurol. 1995;133:225-30.

32. Meshitsuka S, Aremu DA. (13)C Heteronuclear NMR studies of the interaction of cultured neurons and astrocytes and aluminum blockade of the preferential release of citrate from astrocytes. J Biol Inorganic Chem. 2008;13:241-7.

33. Matsuzaki S, Manabe T, Katayama T, Nishikawa A, Yanagita T, Okuda $\mathrm{H}$, et al. Metals accelerate production of the aberrant splicing isoform of the presenilin-2. J Neurochem. 2004; 88:1345-51.

34. Sato N, Imaizumi K, Manabe T, Taniguchi M, Hitomi J, Katayama $\mathrm{T}$, et al. Increased production of beta-amyloid and vulnerability to endoplasmic reticulum stress by an aberrant spliced form of presenilin 2. J Biol Chem. 2001;276:2108-14.

35. Katayama $\mathrm{T}$, Imaizumi $\mathrm{K}$, Manabe $\mathrm{T}$, Hitomi J, Kudo $\mathrm{T}$, Tohyama M. Induction of neuronal death by ER stress in Alzheimer's disease. J Chem Neuroanat. 2004;28:67-78.

36. Reimertz C, Kogel D, Rami A, Chittenden T, Prehn JH. Gene expression during ER stress-induced apoptosis in neurons: induction of the BH3-only protein Bbc3/PUMA and activation of the mitochondrial apoptosis pathway. J Cell Biol. 2003;162:58797.

37. Kim MR, Jeong EG, Chae B, Lee JW, Soung YH, Nam SW, et al. Pro-apoptotic PUMA and anti-apoptotic phospho-BAD are highly expressed in colorectal carcinomas. Dig Dis Sci. 2007;52:2751-6.

38. Reddy RK, Mao C, Baumeister P, Austin RC, Kaufman RJ, Lee AS. Endoplasmic reticulum chaperone protein GRP78 protects cells from apoptosis induced by topoisomerase inhibitors: role of ATP binding site in suppression of caspase-7 activation. J Biol Chem. 2003;278:20915-24.

39. Jurgensmeier JM, Xie Z, Deveraux Q, Ellerby L, Bredesen D, Reed JC. Bax directly induces release of cytochrome $c$ from isolated mitochondria. Proc Natl Acad Sci USA. 1998;95:49975002.

40. Yang J, Liu X, Bhalla K, Kim CN, Ibrado AM, Cai J, et al. Prevention of apoptosis by Bcl-2: release of cytochrome $c$ from mitochondria blocked. Science. 1997;275:1129-32.

41. Jeffers JR, Parganas E, Lee Y, Yang C, Wang J, Brennan J, et al. PUMA is an essential mediator of p53-dependent and -independent apoptotic pathways. Cancer Cell. 2003;4:321-8.

42. Okada T, Yoshida H, Akazawa R, Negishi M, Mori K. Distinct roles of activating transcription factor 6 (ATF6) and doublestranded RNA-activated protein kinase-like endoplasmic reticulum kinase (PERK) in transcription during the mammalian unfolded protein response. Biochem J. 2002;366:585-94.

43. Tirasophon W, Welihinda AA, Kaufman RJ. A stress response pathway from the endoplasmic reticulum to the nucleus requires a novel bifunctional protein kinase/endoribonuclease (Ire1p) in mammalian cells. Genes Dev. 1998;2:1812-24. 
44. Wang XZ, Harding HP, Zhang Y, Jolicoeur EM, Kuroda M, Ron D. Cloning of mammalian Ire1 reveals diversity in the ER stress responses. EMBO J. 1998; 17:5708-17.

45. Lee K, Tirasophon W, Shen X, Michalak M, Prywes R, Okada T, et al. IRE1-mediated unconventional mRNA splicing and S2Pmediated ATF6 cleavage merge to regulate XBP1 in signaling the unfolded protein response. Genes Dev. 2002;16:452-66.

46. Dimcheff DE, Faasse MA, McAtee FJ, Portis JL. Endoplasmic reticulum (ER) stress induced by a neurovirulent mouse retrovirus is associated with prolonged $\mathrm{BiP}$ binding and retention of a viral protein in the ER. J Biol Chem. 2004;279:33782-90.

47. Bertolotti A, Zhang Y, Hendershot LM, Harding HP, Ron D. Dynamic interaction of $\mathrm{BiP}$ and ER stress transducers in the unfolded-protein response. Nat Cell Biol. 2002;2:326-32.

48. Kaufman RJ. Orchestrating the unfolded protein response in health and disease. J Clin Invest. 2002;110:1389-98.

49. Shen J, Chen X, Hendershot L, Prywes R. ER stress regulation of ATF6 localization by dissociation of BiP/GRP78 binding and unmasking of Golgi localization signals. Dev Cell. 2002;3:99111.

50. Rutkowski DT, Kaufman RJ. A trip to the ER: coping with stress. Trends Cell Biol. 2004;14:20-8.

51. Groenendyk J, Michalak M. Endoplasmic reticulum quality control and apoptosis. Acta Biochim Pol. 2005;52:381-95.

52. Michalak M, Robert Parker JM, Opas M. $\mathrm{Ca}^{2+}$ signaling and calcium binding chaperones of the endoplasmic reticulum. Cell Calcium. 2002;32:269-78.

53. Michalak M, Corbett EF, Mesaeli N, Nakamura K, Opas M. Calreticulin: one protein, one gene, many functions. Biochem $\mathrm{J}$. 1999;344:281-92.

54. Saito Y, Ihara Y, Leach MR, Cohen-Doyle MF, Williams DB. Calreticulin functions in vitro as a molecular chaperone for both glycosylated and non-glycosylated proteins. EMBO J. 1999;18: 6718-29.

55. Zuppini A, Groenendyk J, Cormack LA, Shore G, Opas M, Bleackley RC, et al. Calnexin deficiency and endoplasmic reticulum stress-induced apoptosis. Biochemistry. 2002;41:2850-8.

56. Gething MJ. Role and regulation of the ER chaperone BiP. Semin Cell Dev Biol. 1999;10:465-72.

57. Ezomo OF, Matsushima F, Meshitsuka S. Up-regulation in the expression of renin gene by the influence of aluminium. J Inorg Biochem. 2009;103:1563-70.

58. Butkus A, Roche PJ, Fernley RT, Haralambidis J, Penschow JD, Ryan GB, et al. Purification and cloning of a corpuscles of Stannius protein from Anguilla australis. Mol Cell Endocrinol. 1987;54:123-33.

59. Chang AC, Reddel RR. Identification of a second stanniocalcin cDNA in mouse and human: stanniocalcin 2. Mol Cell Endocrinol. 1998;141:95-9.
60. Ishibashi K, Imai M. Prospect of a stanniocalcin endocrine/paracrine system in mammals. Am J Physiol Renal Physiol. 2002;282:F367-75.

61. Ito D, Walker JR, Thompson CS, Moroz I, Lin W, Veselits ML, et al. Characterization of stanniocalcin 2, a novel target of the mammalian unfolded protein response with cytoprotective properties. Mol Cell Biol. 2004;24:9456-9.

62. Murakami T, Kondo S, Ogata M, Kanemoto S, Saito A, Wanaka A, et al. Cleavage of the membrane-bound transcription factor OASIS in response to endoplasmic reticulum stress. J Neurochem. 2006;96:1090-100.

63. Kondo S, Murakami T, Tatsumi K, Ogata M, Kanemoto S, Otori $\mathrm{K}$, et al. OASIS, a CREB/ATF-family member, modulates UPR signalling in astrocytes. Nat Cell Biol. 2005;7:186-94.

64. Carrell RW, Lomas DA. Conformational disease. Lancet. 1997;350:134-8.

65. Hardy J, Selkoe DJ. The amyloid hypothesis of Alzheimer's disease: progress and problems on the road to therapeutics. Science. 2002;297:353-6.

66. Selkoe DJ. Alzheimer's disease: genotypes, phenotypes, and treatments. Science. 1997;275:630-1.

67. Zhang Q, Powers ET, Nieva J, Huff ME, Dendle MA, Bieschke J, et al. Metabolite-initiated protein misfolding may trigger Alzheimer's disease. Proc Natl Acad Sci USA. 2004;101:4752-7.

68. Hoshino T, Nakaya T, Araki W, Suzuki K, Suzuki T, Mizushima T. Endoplasmic reticulum chaperones inhibit the production of amyloid-beta peptides. Biochem J. 2007;402:581-9.

69. Imai Y, Soda M, Hatakeyama S, Akagi T, Hashikawa T, Nakayama KI, et al. CHIP is associated with Parkin, a gene responsible for familial Parkinson's disease, and enhances its ubiquitin ligase activity. Mol Cell. 2002;10:55-67.

70. Nishitoh H, Matsuzawa A, Tobiume K, Saegusa K, Takeda K, Inoue $\mathrm{K}$, et al. ASK1 is essential for endoplasmic reticulum stress-induced neuronal cell death triggered by expanded polyglutamine repeats. Genes Dev. 2002;16:1345-55.

71. Terro F, Czech C, Esclaire F, Elyaman W, Yardin C, Baclet MC, et al. Neurons overexpressing mutant presenilin-1 are more sensitive to apoptosis induced by endoplasmic reticulum-Golgi stress. J Neurosci Res. 2002;69:530-9.

72. Tobisawa S, Hozumi Y, Arawaka S, Koyama S, Wada M, Nagai M, et al. Mutant SOD1 linked to familial amyotrophic lateral sclerosis, but not wild-type SOD1, induces ER stress in COS7 cells and transgenic mice. Biochem Biophys Res Commun. 2003;303:496-503. 